\title{
ПРОБЛЕМНЫЕ ВОПРОСЫ ЗАКЛЮЧЕНИЯ ДОГОВОРА АРЕНДЫ ЗЕМЕЛЬНОГО УЧАСТКА ДЛЯ НУЖД УИС
}

\begin{abstract}
PROBLEM QUESTIONS OF CONCLUSION OF A LAND PLOT LEASE AGREEMENT FOR NEEDS OF PENAL SYSTEM

\author{
L. Rashhupkina \\ A. Serdyuk \\ E. Shorgina
}

Summary. The article discusses the features of the legal regulation of the conclusion of a lease of land for the needs of state institutions and enterprises of the Federal Penitentiary Service of Russia, it concludes that the priority of land legislation over civil law is at the same time, the very procedure for concluding such agreements is regulated by procurement law, since these agreements will be concluded only through the bidding procedure. Particular attention is paid to problematic issues arising from the use of agricultural land by institutions and enterprises of the penal correction system. The authors focus on the fact that, due to certain legislative restrictions, UIS institutions and enterprises cannot be lessors, since the regime for transferring land plots for permanent (unlimited) use directly prohibits, without any exceptions, disposing of this land plot. According to the authors, the analyzed legal relations require a legal settlement up to the introduction of amendments to the federal legislation.
\end{abstract}

Keywords: land plot, rental property, government agency, state contract, operational management, bidding, permanent unlimited use.

B рамках исполнения основных положений «Концепции развития уголовно - исполнительной системы Российской Федерации до 2020 года» в части улучшения материально-бытовых условий и повышения трудовой деятельности и занятости осужденных были обозначены основные мероприятия направленные на расширение производства сельскохозяйственной продукции и стимулирование создания колоний-поселений с сельскохозяйственным производством в зонах с благоприятными климатическими условиями; совершенствование организации питания осужденных и лиц, содержащихся под стражей, в соответствии с международными стандартами; обеспечение продовольственной безопасности и независимости УИС
Ращупкина Людмила Валерьевна

К.ю.н., дочент, Владимирский юридический институт ФСИн России, г. Владимир

rashhupkina73@mail.ru

Сердюк Алевтина Леонидовна

К.ю.н., дочент, Университет ФСИН России, г. Санкт-

Петербург

alevtinaserdyuk@yandex.ru

Шоргина Елена Васильевна

Преподаватель, Владимирский юридический институт ФСИН России, г. Владимир

eshorgina@mail.ru

Аннотация. В статье рассматриваются особенности нормативно-правового регулирования заключения договора аренды земельных участков для нужд казенных учреждений и предприятий ФСИН России, делается вывод 0 приоритете норм земельного законодательства перед гражданским в тоже время сам порядок заключения таких договоров регламентируется законодательством 0 закупках, так как указанные договора будут заключаться только через процедуру проведения торгов. Особое внимание обращается на проблемные вопросы, возникающие при использовании земельных участков сельскохозяйственного назначения учреждениями и предприятиями УИС. Авторы акцентируют внимание на том, что из-за определенных законодательных ограничений, учреждения и предприятия УИС арендодателями быть не могут, так как режим передачи земельных участков в постоянное (бессрочное) пользование, прямо запрещает, без всяких исключений, распоряжаться данным земельным участком. По мнению авторов, проанализированные правоотношения требуют правового урегулирования вплоть до внесения изменений в федеральное законодательство.

Ключевые слова: земельный участок, аренда имущества, казенное учреждение, государственный контракт, оперативное управление, торги, постоянное бессрочное пользование.

от колебаний конъюнктуры рынка питания. За последнее время в УИС сформировалась система внутриведомственных или, как ее еще называют, внутрисистемных поставок, которая позволяет обеспечить заказами производственные подразделения ФСИН России и упростить закупочную деятельность [2, с. 216].

На сегодняшний день проблема развития сельского хозяйства в уголовно-исполнительной системе с целью самообеспеченности продуктами питания, трудоустройством осужденных и извлечения прибыли обсуждается и реализуется руководством ФСИН России, о чем говорят, например, подписанные соглашения о сотрудничестве между различными агрохолдингами и ФСИН России. 
Данные соглашения дают возможность осужденным, отбывающим наказание в колониях-поселениях, трудоустраиваться на предприятия агрохолдинга. Кроме того, они смогут продолжить работать там и после освобождения, таким образом, получая профессиональные навыки, достойную зарплату и необходимые социальные гарантии [3]. Для реализации всех этих масштабных целей и задач встает вопрос о предоставление и использование земельных участков для нужд УИС, которые могут находится как в государственной и муниципальной собственности так и в частной собственности.

Земельные участки давно заняли прочную позицию среди объектов гражданского оборота, в том числе и в учреждениях УИС. Предоставление земельных участков органам и учреждениям ФСИН России возможно на праве постоянного (бессрочного) пользования, на праве безвозмездного пользования и на праве аренды согласно нормам земельного законодательства.

Порядок предоставления земельных участков в постоянное (бессрочное) пользование и безвозмездное пользование казенным учреждениям ФСИН России также регулируется нормами ЗК РФ.

Встает вопрос, какова процедура предоставления земельного участка в аренду для нужд УИС? Какой порядок будет использован казенным учреждением ФСИН России, зависит от категории земельного участка и формы собственности на него. Здесь следует отметить, что выступать в роли арендодателя и сдавать государственные земельные участки в аренду казенное учреждение ФСИН России не может, согласно ст. 269 ГК РФ, лица, которым земельные участки предоставлены в постоянное (бессрочное) пользование, не вправе распоряжаться такими земельными участками. Кроме того, согласно ст. 27 ЗК РФ земельные участки, занятые объектами учреждений и органов ФСИН России изъяты из оборота и не могут быть объектами гражданско-правовых сделок.

На сайте ФСИН России в разделе «Организация совместного производства», не редки предложения об использовании земельных участков в производстве. Здесь возможны различные варианты возникновения договорных правоотношений с представителями бизнеса, это и договор поставки, договор подряда и договор оказания услуг и даже такой договор как «Договор о предоставлении рабочей силы из числа осужденных», который по своим характеристикам не подходит ни под гражданско-правовое ни под трудовое регулирование, все вышеуказанные договора заключаются с основной целью - трудоустройство осужденных. Таким образом, земельные участки, находящиеся в государственной собственности и предоставленные казенным учреждениям и предприятиям ФСИН России на праве постоян- ного (бессрочного) пользования не могут передаваться таким бизнес-субъектам ни по договору аренды, так как они ограничены в обороте, ни в безвозмездное пользование, по прежнему сохраняя статус закрепленных за конкретным учреждением, по сути на них организовывается производство без передачи какого либо права на данный земельный участок.

Арендные правоотношения, где объектом выступают земельные участки регулируются земельным и гражданским законодательством, причем приоритет земельного над гражданским законодательством очевиден, что указывается в п. 3 ст. 3 ЗК РФ. Однако законодатель не исключил регулирование земельных отношений специальными федеральными законами. Аренда земельных участков регулируется общими положениями об аренде с учетом содержащихся в них специальных правил об аренде недвижимости и специальными нормами земельного законодательства и иного законодательства, устанавливающего особые правила об отдельных видах земельных участков.

В Российской Федерации земельные участки, за исключением указанных в п. 4 ст. 27 ЗК РФ, могут быть предоставлены их собственниками в аренду в соответствии с нормами земельного и гражданского законодательства. Как было указано выше, учреждения УИС не могут выступать в качестве арендатора, если предметом договора является земельный участок. Следует отметить, что здания, строения, сооружения, находящиеся на земельных участках учреждений ФСИН России, не будут относятся к объектам, изъятым из оборота. Причем в п. 4 ст. 27 ЗК РФ норма сформулирована таким образом, что при буквальном ее толковании видно, что ограничены в обороте должны быть только те земельные участки, на которых расположены объекты учреждений и органов ФСИН России. Виды предприятий, учреждений и организаций, входящих в уголовно-исполнительную систему перечислены в Постановление Правительства РФ от 01.02.2000 № 89 «Об утверждении перечня видов предприятий, учреждений и организаций, входящих в уголовно-исполнительную систему». Все, указанные предприятия, учреждения, организации УИС располагаются в зданиях, строениях сооружениях, которые в свою очередь причисляются ГК РФ к объектам недвижимости. Заметим, что сами объекты недвижимости УИС или их часть не изымаются из оборота и могут сдаваться в аренду и передаваться в безвозмездное пользование, соблюдая определенную процедуру согласования таких договоров [4, с. 177]. Но на землях сельскохозяйственного назначения, закрепленных за учреждениями и органами ФСИН России, как правило, объектов, относящихся непосредственно к УИС, режимных, административных, ведомственных, нет. Согласно ст. 77 ЗК РФ земли сельскохозяйственного назначения могут быть заняты только 
зданиями, сооружениями, используемыми для производства, хранения и первичной переработки сельскохозяйственной продукции, которые являются неотъемлемой частью обработки данных площадей. «Излишки» земель сельскохозяйственного назначения, закрепленных за ФСИН России на праве постоянного (бессрочного) пользования, учреждения могли бы сдавать в аренду и извлекать из этого прибыль получая доход в виде арендной платы, тем самым пополняя бюджет. Чтобы это могло быть реализовано, считаем целесообразным внести следующие изменения:

- в п. 3 ст. 269 ГК РФ, изложив ее в следующей редакции: «Лица, которым земельные участки предоставлены в постоянное (бессрочное) пользование, не вправе распоряжаться такими земельными участками, за исключением случаев установленных Земельным кодексом Российской Федерации»,

- в ст. 39.9 ЗК РФ, дополнив ее п. 5 «Лица, за которыми земельный участок закреплен на праве постоянного (бессрочного) пользования, владеют, пользуются этим имуществом в пределах, установленных законом, в соответствии с целевым назначением и разрешенным использованием, и, распоряжается этим имуществом с согласия собственника этого имущества».

- в п. 4 ст. 27 ЗК РФ, сформулировав ее следующим образом: «Из оборота изъяты земельные участки, занятые находящимися в федеральной собственности следующими объектами: 8) объектами учреждений и органов Федеральной службы исполнения наказаний, кроме земельных участков, относящихся к землям сельхозназначения».

Но не во всех учреждениях и предприятиях УИС имеются земельные участки, либо их недостаточно, в таких случаях учреждение или предприятие может выступать как арендатор и такая востребованность есть, об этом говорят сведения, представленные в Единой информационной системе в сфере закупок [2].

Заказчиком закупки аренды земельных участков в основном выступают унитарные предприятия ФСИН России, но в некоторых случаях и учреждения, например, ФКУ КП-8 УФСИН России по Белгородской области. Объектом закупки, чаще всего, являются земельные участки сельскохозяйственного назначения, с разрешенным использованием (назначением) участка: под ведение сельскохозяйственного производства. Заключаются такие договора в целях исполнения государственных контрактов на поставку различной сельскохозяйственной продукции. Как правило, такие договора имеют сезонное значение и заключаются соответственно на срок от посевных работ до сборки урожая.
Договор аренды - это договор гражданско-правового характера, по которому арендодатель обязуется предоставить арендатору имущество за плату во временное владение и пользование или во временное пользование.

Из приведенного определения следует, что одним из важных условий договора аренды, а главное, условием сохранения договорных отношений является своевременное внесение арендной платы за временное пользование имуществом, принадлежащим на праве собственности арендодателю.

Если земельный участок находится в государственной или муниципальной собственности, то арендная плата будет устанавливаться в соответствии со ст. 39.7 ЗК РФ и Постановлением Правительства РФ от 16.07.2009 № 582 «Об основных принципах определения арендной платы при аренде земельных участков, находящихся в государственной или муниципальной собственности, и «Правилами определения размера арендной платы, а также порядка, условий и сроков внесения арендной платы за земли, находящиеся в собственности Российской Федерации». В случае, когда учреждение УИС берет для своих нужд земельный участок в аренду у частных лиц, то арендная плата определяется нормами гражданского законодательства с учетом требований Федерального закона от 05.04.2013 № 44-Ф3 «О контрактной системе в сфере закупок товаров, работ, услуг для обеспечения государственных и муниципальных нужд» (далее: закон № 44-Ф3). Так как земельный участок выступает объектом закупки, начальная (максимальная) цена контракта определяется и обосновывается заказчиком посредством применения методов, указанных в ст. 22 Закона № 44-Ф3. Чаще всего, согласно методических рекомендаций по применению методов определения начальной (максимальной) цены контракта, заключаемого с единственным поставщиком (подрядчиком, исполнителем) утвержденным приказом Минэкономразвития России от 02.10.2013 г. № 567, проводится маркетинговое исследование на предмет установления начальной (максимальной) цены государственного контракта по аренде участка сельскохозяйственного назначения для выращивания сельскохозяйственных культур (картофель, свекла) для нужд учреждения и используется метод сопоставимых рыночных цен (анализ рынка). Расчет и обоснование цены контракта с обоснованием применяемого метода расчета цены указываются в извещении и приложении к контракту.

Закупка аренды земельного участка для нужд учреждений УИС будет проводится посредством проведения торгов, и оформляться через госконтракт. Регулируются данные правоотношения нормами Закона № 44-Ф3, ЗК РФ и гражданским законодательством. Казенные учреждения УИС, в данном случае, являются государственным заказчиком, действующим от имени Российской Федерации, 
уполномоченное принимать бюджетные обязательства и осуществляющее закупки. Если государственным заказчиком будет федеральное государственное унитарное предприятие, входящее в состав УИС, то закупка аренды будет проводится по Федеральному закону от 18.07.2011 № 223-Ф3 «О закупках товаров, работ, услуг отдельными видами юридических лиц» (далее: Закон № 223-ФЗ).
Таким образом, при осуществлении арендных правоотношений, объектом которых будет земельный участок, у учреждений УИС возникает ряд проблемных вопросов, которые требуют, на сегодняшний момент, нормативного закрепления, что позволило бы данным субъектам быть полноправными участниками производства и гражданского оборота.

\section{ЛИТЕРАТУРА}

1. Единая информационная система в сфере закупок: [сайт].— URL: https://zakupki.gov.ru/epz/main/public/home.html (дата 0бращения: 30.01.2020).

2. Пружинина 0.П. Особенности закупок продовольствия для нужд УИС. Сборник: Юридическая наука и практика альманах научных трудов Самарского юридического института ФСИН России. 2016. С. 215-216.

3. Федеральная служба исполнения наказаний: [сайт].—URL: http://фсин.pф/news/index.php? ELEMENT_ID=399160 (дата 0бращения: 29.01.2020).

4. Шоргина Е. В. Порядок заключения договора аренды имущества для государственных нужд уголовно-исполнительной системы. Вестник Кузбасского института. 2019. № 1 (38). С. 174-180.

๑ Ращупкина Людмила Валерьевна ( rashhupkina73@mail.ru ),

Сердюк Алевтина Леонидовна ( alevtinaserdyuk@yandex.ru ), Шоргина Елена Васильевна ( eshorgina@mail.ru ).

Журнал «Современная наука: актуальные проблемы теории и практики»

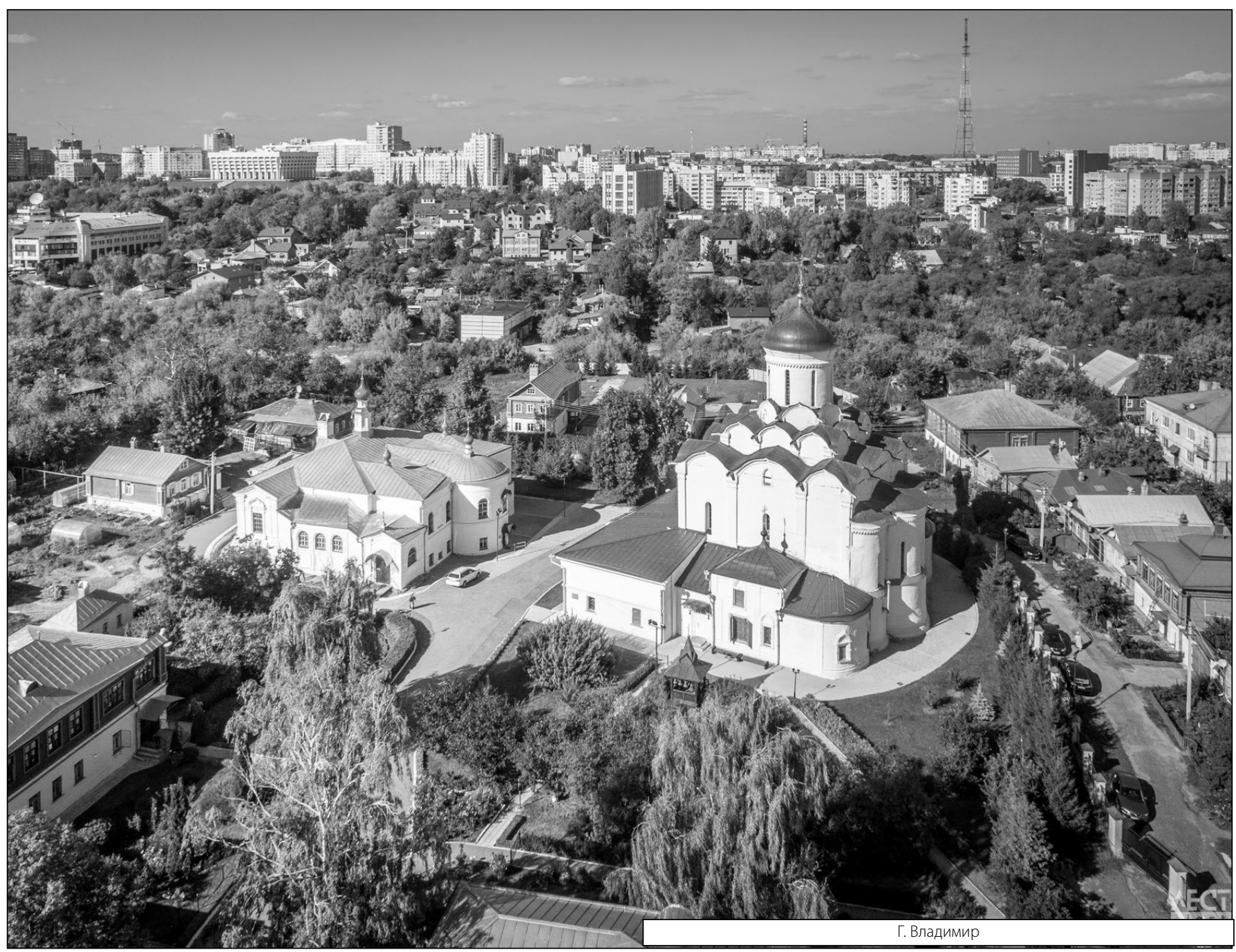

